\title{
The settlement of anthropogenic water-bodies of Silesia by Ferrissia clessiniana (Jickeli)
}

\author{
MAŁGORZATA STRZELEC \\ Department of Hydrobiology, Silesian University, Bankowa 9, P-40-007 Katowice, Poland, e-mail strzelec @ us.edu.pl
}

\begin{abstract}
STRZELEC M., 2005: The settlement of anthropogenic water-bodies of Silesia by Ferrissia clessiniana (Jickeli). - Malacologica Bohemoslovaca, 4: 5-9. Online serial at $<$ http://mollusca.sav.sk> 4-Aug-2005.
\end{abstract}

In last two decades Ferrissia clessiniana (Jickeli, 1802) was observed in anthropogenic waterbodies in Silesia (Southern Poland). Formerly this species was found only in Western and Central Poland. In Silesia it settles the subsidence ponds, sand- and gravel-pits and dam reservoirs, where lives mostly in the rush belts. In the absence of vegetation $F$. clessiniana inhabits the stones, covered with periphyton layer, and the remains of decayed water-plants and leaves of waterside trees. Never forms the dense populations.

\section{Introduction}

The settlement of freshwater habitats by molluscs is interesting because of the rate of appearance in newly created in result of human activity waterbodies (STRZELEC 1993). Origin of such habitats makes up for the disappearance of natural freshwater environments, what is the cause of loss in biodiversity on the disturbed area. Most of anthropogenic water-bodies despite of their origin are small and their water level varies periodically during year.

In small anthropogenic reservoirs in which small diversity of niches occurs, the disturbance of environmental conditions are easily perceptible. In result, in such water bodies, particularly when they are situated in regions being under intensive human impact the animal species diversity is in general smaller than in natural freshwater habitats (STRZELEC \& SERAFIŃSKI 2004).

In anthropogenic water-bodies the alien animal species sometimes appear, coming from other geographical regions, and influence the native fauna, causing at times its impoverishment. This fact was noted in relation to the new-zealand mudsnail (Potamopyrgus antipodarum), which in settled various habitats reduced the abundance and diversity of native snail communities (STRZELEC 1992). The survival of invaders in new habitat depends on different environmental factors, namely habitat stability, physico-chemical water characters, vegetation and food abundance, as well as the kinds of bottom sediments. It is the cause that the most successful colonisers among snails are the ubiquitous, tolerant species (STRZELEC \& SERAFIŃSKI 2004).

In the second half of $20^{\text {th }}$ century on the urbanized and industrialized area of Silesia three alien snail species were observed to the first time in anthropogenic water-bodies. They were: mediterranean Physella acuta (Draparnaud) from the early seventies, new-zealand Potamopyrgus antipodarum (Gray) from eighties and Ferrissia clessiniana (Jickeli) from the last two decades.

The first findings of the last species are known from 1986, when it was found in artificially heated Konin lakes in Central Poland and published under the name Ferrissia wautieri (Mirolli) by PIECHOCKI (1986). In following years it was found in single habitats of stagnant waters in Central and Northern Poland (BERNARD 1994, WŁOSIK-BIEŃCZAK 1994, STRZELEC \& LEWIN 1996), whereas in neighbouring regions the number of Ferrissia clessiniana findings increased from year to year (e.g. BERAN 2002).

In above-mentioned regions of Poland, Ferrissia clessiniana co-occurred always together with Gyraulus albus and Radix peregra and often with Segmentina nitida and Lymnaea stagnalis. All collected specimens were found on partly decayed 
remains of Typha latifolia or on its living stems, but not on other plants of abundant vegetation.

\section{Study area and study sites}

Silesia, the southern area of Poland, bordering upon Czech Republic, is the most industrialized and urbanized region of the country. During thirty years of malacological studies, which have included more than 250 anthropogenic water bodies, the first findings of Ferrissia clessiniana were known from the late ninetieths and during next years it was found in 17 habitats of different origin and kind. There were sand- and gravel-pits [Nos. 1-2 Graboszyce $\left(50^{\circ} 02^{\prime} \mathrm{N}, 19^{\circ} 14^{\prime} \mathrm{E}\right), 3$ - Dzierżno $\left(50^{\circ} 17^{\prime} \mathrm{N}, 18^{\circ} 40^{\prime} \mathrm{E}\right), 4-$ Sosnowiec $\left(50^{\circ} 18^{\prime} \mathrm{N}\right.$, $\left.19^{\circ} 10^{\prime} \mathrm{E}\right), 5$ - Tychy $\left(50^{\circ} 08^{\prime} \mathrm{N}, 18^{\circ} 59^{\prime} \mathrm{E}\right), 6-$ Zabrze $\left.\left(50^{\circ} 19^{\prime} \mathrm{N}, 18^{\circ} 47^{\prime} \mathrm{E}\right)\right]$, subsidence ponds [7 - Siemianowice $\left(50^{\circ} 18^{\prime} \mathrm{N}, 19^{\circ} 02^{\prime} \mathrm{E}\right), 8-9$ - Czułów $\left(50^{\circ} 08^{\prime} \mathrm{N}, 18^{\circ} 59^{\prime} \mathrm{E}\right), 10$ - Zabrze, 11 - Knurów $\left.\left(50^{\circ} 13^{\prime} \mathrm{N}, 18^{\circ} 40^{\prime} \mathrm{E}\right)\right]$ and dam reservoirs [12-14 Katowice $\left(50^{\circ} 16^{\prime} \mathrm{N}, 19^{\circ} 01^{\prime} \mathrm{E}\right), 15-17$ - Rybnik $\left.\left(50^{\circ} 07^{\prime} \mathrm{N}, 18^{\circ} 32^{\prime} \mathrm{E}\right)\right]$.

The general characteristics of these kinds of waterbodies are given in STRZELEC \& SERAFIŃSKI (2004). They differ in respect of area and depth. Pits and subsidence ponds are small, rarely of area greater than several ha, whereas the area of dam reservoirs exceeds sometimes several hundreds ha. Most of studied water-bodies are situated near urban agglomerations and are under heavy human impact. Their bottom is differently developed because of various origin. For subsidence ponds characteristic is bottom with thick layer of mud, with great addition of mineral substances. In pits and dam-reservoirs the bottom is of sand or gravel, covered with thin layer of silt.

In sunny places on stable bottom in all water-bodies occurred the plant conglomerations of various abundance and diversity, dependent on the fluctuation of water level, caused by seasonal changes of temperature as well as by human intervention.

During study period 17 species of water plants were found in studied habitats, most of them are characteristic for eutrophic conditions. The occurrence of plant species in particular sites is shown in Table 1.

In subsidence ponds and dam reservoirs the most common were Typha latifolia and Glyceria maxima, whereas in pits Elodea canadensis and Acorus calamus. Only in dam-reservoir the rushbelts of Phragmites australis and Glyceria aquatica were observed.

\section{Material and methods}

The snails were gathered from the area of $1 \mathrm{~m}^{2}$ in each water-body, from plant remains and living plants, stones and submerged objects, as well as from sieved bottom sediments. The sampling sites were selected according to environmental diversity. Materials were collected in summer months.

The nomenclature of snail species is adapted from GLÖER \& MEIER-BROOK (1998).

In tables the density of snails (as individuals per $1 \mathrm{~m}^{2}$ ) is given as follows:
A...single specimen
B...2-5 specimens
C...6-10 specimens
D...above 10 specimens

\section{Results and discussion}

In the study area Ferrissia clessiniana were found most commonly on submerged leaves of water plants and on stems of Typha latifolia and Glyceria aquatica. In the absence of plant it settled the submerged stones covered with periphyton layer (as Dzierżno and Czułów), the decayed leaves of waterside trees (in Zabrze) and the plant detritus deposited on the bottom.

The periodical fluctuation of water level and even its lack in some periods, what is characteristic for postindustrial water-bodies, are the factors limiting the occurrence of snails. Although Ferrissia clessiniana has at disposal the adaptation to the survival of dry periods in form of septum formation in young individuals, in studied periodically drying habitats the septal forms were found only rarely. In all water-bodies Ferrissia clessiniana occurred mainly in littoral insolated zone together with 16 other snail species (Table 2). In particular waterbodies there occurred from 3 to 11 species. The cooccurrence of some species with Ferrissia clessiniana was very different one. In dam reservoirs it was found most often with Potamopyrgus antipodarum and Physella acuta, in sand and gravel-pits with Radix peregra and Gyraulus albus, whereas in subsidence ponds with Segmentina nitida, Radix auricularia and Planorbarius corneus.

The most interesting is the occurrence of big population of studied species in artificially heated dam-reservoirs in Rybnik (STRZELEC 1999). It seems that this mediterranean species was confronted there with particularly convenient conditions, what resulted in increase of population size. It was observed in relation to other species introduced from warmer than central-European climate, e.g. Physella acuta and Potamopyrgus antipodarum.

Similarly as in other regions the populations Ferrissia clessiniana undergo changes during year. Independently of their size they appear and disappear alternately in the same place. It may result both of reproductive processes and of the translocations conditioned by day length. 
Table 1. The vegetation of particular water- bodies.

\begin{tabular}{|c|c|c|c|c|c|c|c|c|c|c|c|c|c|c|c|c|c|c|}
\hline & \multirow[t]{2}{*}{ Species } & \multicolumn{6}{|c|}{ Sand-and gravel- pits } & \multicolumn{5}{|c|}{ Subsidence ponds } & \multicolumn{6}{|c|}{ Dam reservoirs } \\
\hline & & 1 & 2 & 3 & 4 & 5 & 6 & 7 & 8 & 9 & 10 & 11 & 12 & 13 & 14 & 15 & 16 & 17 \\
\hline 1 & Polygonum amphibium L. & & & & & & & $\mathrm{X}$ & $\mathrm{X}$ & & & & & $\mathrm{X}$ & & $\mathrm{X}$ & $\mathrm{X}$ & $\mathrm{X}$ \\
\hline 2 & Nuphar lutea (L.) Sm & & & & & & & & & & & & & & $\mathrm{X}$ & & & \\
\hline 3 & Ceratophyllum demersum L. & $\mathrm{X}$ & & & $\mathrm{X}$ & & & & $\mathrm{X}$ & & & $\mathrm{X}$ & & & & $\mathrm{X}$ & $\mathrm{X}$ & \\
\hline 4 & Myriophyllum verticillatum L. & $\mathrm{X}$ & & & $\mathrm{X}$ & $\mathrm{X}$ & & & $\mathrm{X}$ & $\mathrm{X}$ & & & & & & & & \\
\hline 5 & Sagittaria sagittifolia L. & $\mathrm{X}$ & & & & & & & & & & & & & & & & \\
\hline 6 & Alisma plantago-aquatica L. & & & & & & & & $\mathrm{X}$ & & & & & & & & & \\
\hline 7 & Hydrocharis morsus ranae L. & & $\mathrm{X}$ & & & & $\mathrm{X}$ & & & & & & & & & & & $\mathrm{X}$ \\
\hline 8 & Elodea canadensis Michx. & $X$ & $\mathrm{X}$ & & $\mathrm{X}$ & & $\mathrm{X}$ & & $X$ & & & $\mathrm{X}$ & & & & & & \\
\hline 9 & Potamogeton natans L. & & $\mathrm{X}$ & & $\mathrm{X}$ & $\mathrm{X}$ & & $\mathrm{X}$ & & & & $\mathrm{X}$ & & & & & & \\
\hline 10 & Potamogeton crispus L. & $\mathrm{X}$ & & & $\mathrm{X}$ & & & $\mathrm{X}$ & $\mathrm{X}$ & $\mathrm{X}$ & & & & & & & & \\
\hline 11 & Iris pseudoacorus L. & $\mathrm{X}$ & & & & & & & $\mathrm{X}$ & $\mathrm{X}$ & & & & & & & & \\
\hline 12 & Schoenoplectus lacustris (L.) Palla & & & & & & & & & & & & & & & & $\mathrm{X}$ & \\
\hline 13 & Phragmites australis (Cav.) & & & $\mathrm{X}$ & & & & $\mathrm{X}$ & & & & $\mathrm{X}$ & $\mathrm{X}$ & $\mathrm{X}$ & & $\mathrm{X}$ & $\mathrm{X}$ & $\mathrm{X}$ \\
\hline 14 & Glyceria aquatica (L.) Wahlb & & & $\mathrm{X}$ & & & & $\mathrm{X}$ & $\mathrm{X}$ & $\mathrm{X}$ & $\mathrm{X}$ & & $\mathrm{X}$ & $\mathrm{X}$ & $\mathrm{X}$ & & $\mathrm{X}$ & $\mathrm{X}$ \\
\hline 15 & Lemna minor L. & & $\mathrm{X}$ & & & & $\mathrm{X}$ & $\mathrm{X}$ & $\mathrm{X}$ & & $\mathrm{X}$ & & & & $\mathrm{X}$ & $\mathrm{X}$ & $\mathrm{X}$ & $\mathrm{X}$ \\
\hline 16 & Acorus calamus L. & $\mathrm{X}$ & $\mathrm{X}$ & & & $\mathrm{X}$ & $\mathrm{X}$ & & $\mathrm{X}$ & & & & & & & & & \\
\hline 17 & Typha latifolia L. & & & & $\mathrm{X}$ & $\mathrm{X}$ & $\mathrm{X}$ & $\mathrm{X}$ & $\mathrm{X}$ & $\mathrm{X}$ & $\mathrm{X}$ & $\mathrm{X}$ & $\mathrm{X}$ & $\mathrm{X}$ & & $\mathrm{X}$ & $\mathrm{X}$ & $\mathrm{X}$ \\
\hline & Species number & 7 & 5 & 2 & 6 & 4 & 5 & 7 & 11 & 5 & 3 & 5 & 3 & 4 & 3 & 5 & 7 & 6 \\
\hline
\end{tabular}


Table 2. The snail communities in particular water-bodies.

\begin{tabular}{|c|c|c|c|c|c|c|c|c|c|c|c|c|c|c|c|c|c|c|}
\hline & \multirow[t]{2}{*}{ Species } & \multicolumn{6}{|c|}{ Sand and gravel pits } & \multicolumn{5}{|c|}{ Subsidence ponds } & \multicolumn{6}{|c|}{ Dam reservoirs } \\
\hline & & 1 & 2 & 3 & 4 & 5 & 6 & 7 & 8 & 9 & 10 & 11 & 12 & 13 & 14 & 15 & 16 & 17 \\
\hline 1 & Potamopyrgus antipodarum (Gray, 1843) & & & $\mathrm{A}$ & & $\mathrm{D}$ & & $\mathrm{C}$ & & $\mathrm{D}$ & & & $\mathrm{D}$ & $\mathrm{C}$ & $\mathrm{D}$ & $\mathrm{D}$ & $\mathrm{D}$ & $\mathrm{D}$ \\
\hline 2 & Bithynia tenatculata (Linnaeus, 1758) & & & & & & & & $\mathrm{A}$ & & & & & & & & & \\
\hline 3. & Physa fontinalis (Linnaeus, 1758) & & & & & & & & & & & & & & & & & $\mathrm{D}$ \\
\hline 4 & Physella acuta (Draparnaud, 1805) & & & & $\mathrm{D}$ & $\mathrm{B}$ & & & & & & & $\mathrm{D}$ & $\mathrm{D}$ & $\mathrm{B}$ & $\mathrm{C}$ & $\mathrm{C}$ & \\
\hline 5 & Lymnaea stagnalis (Linnaeus, 1758) & $\mathrm{B}$ & $\mathrm{D}$ & & & A & & & $\mathrm{B}$ & $\mathrm{B}$ & $\mathrm{D}$ & & & & & & & $\mathrm{B}$ \\
\hline 6 & Radix peregra (O.F. Müller, 1774) & $\mathrm{D}$ & $\mathrm{D}$ & $\mathrm{B}$ & $\mathrm{D}$ & $\mathrm{D}$ & $\mathrm{B}$ & & & $\mathrm{A}$ & & $\mathrm{B}$ & & & & $\mathrm{A}$ & $\mathrm{B}$ & $\mathrm{B}$ \\
\hline 7 & Radix auricularia (Linnaeus, 1758) & $\mathrm{A}$ & & $\mathrm{C}$ & & & & $\mathrm{D}$ & $\mathrm{A}$ & & $\mathrm{D}$ & & & & & & & \\
\hline 8 & Planorbis planorbis (Linnaeus, 1758) & & & $\mathrm{B}$ & $\mathrm{A}$ & & & & & & & & & & & $\mathrm{A}$ & & $\mathrm{D}$ \\
\hline 9 & Galba truncatula (O.F. Müller, 1774) & & & $\mathrm{D}$ & & & & & & & & & & & & & & \\
\hline 10 & Anisus vortex (Linnaeus, 1758) & $\mathrm{B}$ & $\mathrm{A}$ & & $\mathrm{A}$ & & & & & & & & & & & & & $\mathrm{D}$ \\
\hline 11 & Bathiomphalus contortus (Linnaeus, 1758) & & & & & & $\mathrm{D}$ & & & & $\mathrm{B}$ & & & & & & & \\
\hline 12 & Gyraulus albus (O.F. Müller, 1774) & $\mathrm{D}$ & $\mathrm{D}$ & $\mathrm{A}$ & $\mathrm{C}$ & $\mathrm{D}$ & $\mathrm{B}$ & & $\mathrm{B}$ & $\mathrm{B}$ & $\mathrm{B}$ & $\mathrm{D}$ & & & $\mathrm{B}$ & $\mathrm{C}$ & & $\mathrm{B}$ \\
\hline 13 & Armiger crista (Linnaus, 1758) & & $\mathrm{A}$ & $\mathrm{A}$ & $\mathrm{B}$ & & & & & & & & & & $\mathrm{D}$ & & & $\mathrm{B}$ \\
\hline 14 & Segmentina nitida (O.F. Müller, 1774) & $\mathrm{B}$ & A & & $\mathrm{B}$ & & & & $\mathrm{A}$ & $\mathrm{A}$ & $\mathrm{B}$ & $\mathrm{D}$ & & $\mathrm{D}$ & $\mathrm{B}$ & $\mathrm{B}$ & & $\mathrm{B}$ \\
\hline 15 & Planorbarius corneus (Linnaeus, 1758) & & & & & & $\mathrm{A}$ & & $\mathrm{B}$ & $\mathrm{A}$ & $\mathrm{D}$ & $\mathrm{C}$ & & & & $\mathrm{A}$ & & $\mathrm{B}$ \\
\hline 16 & Ferrissia clessiniana (Jickeli, 1802) & $\mathrm{B}$ & $\mathrm{A}$ & $\mathrm{B}$ & $\mathrm{D}$ & $\mathrm{D}$ & $\mathrm{D}$ & $\mathrm{D}$ & $\mathrm{D}$ & $\mathrm{B}$ & $\mathrm{C}$ & $\mathrm{B}$ & $\mathrm{B}$ & $\mathrm{B}$ & $\mathrm{D}$ & $\mathrm{D}$ & $\mathrm{C}$ & $\mathrm{C}$ \\
\hline 17 & Acroloxus lacustris (Linnaeus, 1758) & & $\mathrm{B}$ & & & A & & & $\mathrm{A}$ & & & & & & & & & \\
\hline 18 & Species number & 7 & 8 & 8 & 8 & 7 & 5 & 3 & 8 & 7 & 7 & 5 & 3 & 4 & 6 & 8 & 4 & 11 \\
\hline
\end{tabular}


According to LILL (1990) Ferrissia clessiniana spreads along river-systems in plant remains while by birds and men assistance to isolated water bodies. From among studied habitats only subsidence ponds are beyond the flowing systems. It is, together with unfavorable physico-chemical conditions, the reason that proportionally fewer habitats of the last kind are colonized by Ferrissia clessiniana.

The obtained results show any negative impact on the native snail fauna, what was stated in relation to Potamopyrgus antipodarum in postindustrial ponds (STRZELEC 2005).

\section{Acknowledgement}

This work was partly funded by grant of Committee of Science Researches no 2 PO4 G076 26 pO1.

\section{References}

BERAN L., 2002: Vodní měkkýši České republiky rozšíření a jeho změny, stanoviště, šíření, ohrožení a ochrana, červený seznam [Aquatic molluscs of the Czech Republic distribution and its changes, dispersal, threat and protection, Red List]. Sborník Př́rodovědného klubu $\mathrm{v}$ Uherském Hradišti, Supplementum 10, 258 pp.

BERNARD R., 1994: New localities of the freshwater limpet Ferrissia wautieri (Mirolli 1960) (Gastropoda: Basommatophora: Ancylidae) in Poland. Mitteilungen deutschen malakozoologischen Gesellschaft, 53: 19-21.

GlÖER P. \& MEIER-BROOK C., 1998: Süsswassermollusken. - 12 Aufl., DJN, Hamburg, 136 pp.

LILL K., 1990: Neue Daten zur Ausbreitung der flachen Mützenschnecke Ferrissia wautieri (Mirolli 1960) (Gastropoda: Bassomatophora: Ancylidae) in Niedersachsen und Bremen. - Mitteilungen deutschen malakozoologischen Gesellschaft, 46: 9-14.

PIECHOCKI A., 1986: Ferrissia wautierri (Mirolli) Gastropoda, Ancylidae nowy gatunek ślimaka dla fauny Polski [Ferrissia wautieri (Mirolli) Gastropoda Ancylidae new species for the Polish fauna]. - Przegląd Zoologiczny, 30 (3): 299-303.

STRZELEC M., 1992: Fauna Ślimaków wodnych projektowanego rezerwatu ornitologicznego „Żabie Doły" w Bytomiu [Aquatic molluscs of the prepared ornithological reserve „Żabie Doły“ in Bytom]. - Kształtowanie Środowiska Geograficznego. Ochrona Przyrody Obszarów Zurbanizowanych, 4: 44-48.

STRZELEC M., 1993: Ślimaki (Gastropoda) antropogenicznych środowisk wodnych Wyżyny Śląskiej [Snails (Gastropoda) of anthropogenic water environments in Silesian Upland]. - Prace Naukowe Uniwersytetu Śląskiego, Katowice, $1358,104 \mathrm{pp}$.

STRZELEC M., 1999: The effects of elevated water temperature on occurrence of freshwater snails in Rybnik dam reservoir (Upper Silesia, Poland). Folia Malacologica, 7: 93-98.

STRZELEC M., 2005: Impact of the introduced Potamopyrgus antipoadrum (Gastropoda) on the snail fauna in post-industrial ponds in Poland. Biologia, Bratislava, 60 (2): 159-163.

STRZELEC M. \& LEWIN I., 1996: Some data on the distribution and biology of Ferrissia wautieri (Mirolli 1960) in Southern Poland (Gastropoda: Ancylidae). - Mitteilungen deutschen malakozoologischen Gesellschaft, 58: 23-26.

STRZELEC M. \& SERAFIŃSKI W., 2004: Biologia i ekologia ślimaków w zbiornikach antropogenicznych [Biology and ecology of snails in anthropogenic stands]. - Centrum Dziedzictwa Przyrody Górnego Śląska, Katowice, 90 pp.

WŁosIK-BIEŃCZAK E., 1997: Mięczaki (Mollusca) rzeki Cybiny i sztucznych zbiorników wodnych utworzonych w jej biegu w granicach miasta Poznania w latach 1992-1994 [Mollucs (Mollusca) of the river Cybina and man made water reservoirs along its course within the borders of Poznań town in the year 1992-1994]. - Badania Fizjograficzne nad Polską Zachodnią, Seria C, Zoologia, 44: 1940. 